\title{
Editorial
}

\section{Cultivating our readers' experience: critical reviews}

Marta Regina de Leão D'Agord*1

In 2020, the Revista Latinoamericana de Psicopatologia Fundamental (Latin American Journal of Fundamental Psychopathology $-R L P F)$ celebrates its $22^{\text {nd }}$ anniversary and the current issue is the latest one of an unbroken sequence of 92 quarterly editions. The journal was launched at the III Brazilian Congress of Fundamental Psychopathology in 1998 to disseminate research in fundamental psychopathology. In the editorial of the second issue, Manoel Tosta Berlinck announced that it would feature the work of those who, in or outside academic institutions, dedicate themselves to systematic research in psychopathology. The Journal owes much to Manoel's editorial work, who was then the head of the University Network for Research in Fundamental Psychopathology, the future University Association for Research in Fundamental Psychopathology (AUPPF).

The first issue of the Journal presented three sections: Editorial, Articles, Reviews. However, heterogeneity, one of the psychopathology's features, was taken into account and additional

${ }^{* 1}$ Universidade Federal do Rio Grande do Sul UFRGS (Porto Alegre, RS. Brasil). 
sections were added: Interview, History of Psychiatry, Observing Medicine, Observing Psychiatry, Mental Health, Classics of Psychopathology, First Steps, Literary Movements, History of Psychoanalysis, Epistemology of Psychopathology, and Literature, Arts, Culture. Later, some of these were discontinued, while others were renamed.

RLPF's Reviews section has been active since the first issue, but its format and name were changed. Revisiting the first reviews published by the journal is like opening a time capsule. I want to to invite our readers to follow me on that path. In the journal's second issue, the Reviews section was divided into two parts, Book Reviews and Article Reviews. The latter, then edited by Mario Eduardo Costa Pereira, aimed at updating readers on international research in the field of psychopathology. This proposal bore fruit from the first article reviewed: a research report published by the American Journal of Psychiatry in that year. The author of the article was none other than Eric Kandel, a scientist familiar with psychoanalysis practiced in the United States who would be awarded the Nobel Prize two years later for his research in the field of memory. This section excelled in sharing the content of recent publications exclusively accessible in English and unavailable on the Internet at the time, such as the American Journal of Psychiatry Science, Scientific American, British Journal of Psychiatry, New England Journal of Medicine, Archives of General Psychiatry, Journal of Forensic Psychiatry On-Line, Psychosomatics, Lancet, British Journal of Psychiatry. Articles published in Spanish and Portuguese by, e.g., Acheronta, Revista de Psicologia (PUC-Rio), and Revista de Psiquiatria Clínica were also reviewed.

The Book Reviews section contains on average two reviews on the latest publications in the field. By 2007, the main international journals had become accessible on the web, and the Article Reviews section was discontinued. In addition, our Journal, until then available on AUPPF's portal, was included in the SciELO collection of periodicals in 2008. Between 2008 and 2010, the Article Reviews section was resumed in a new format, which consisted of critical comment on at least four articles on a given topic that had been published in national and international journals.

Guilherme Gutman (2008) presented it as follows:

May this section be like 'a good peer, in terms of profession and interests'. May it be useful e.g., in choosing what to read and what not read in these times of unmanageable volumes of articles and periodicals [...]. This section mainly aims to invite readers to participate in the game: experiment the texts, take the 
risk inherent in reading, i.e., interpret, reflect and elaborate on what you read. (pp. 515-516)

The critical function of this section is still a highlight today due to Sonia Leite's collaboration, who joined us in 2013. In 2015, the Reviews section was renamed to Literature Reviews. Still in 2015, Sonia Leite wrote a guideline on how to write critical reviews, which is published in summarized form in RLPF's Instructions to authors. The comments by the review's author have gained relevance. A critical review is expected to analyze, examine and assess a recent book or text so as to help readers select what to read.

A critical review published in the Literature Reviews section should evaluate the relevance of a recent publication, if possible, in a delicate style, so as to arouse interest in reading.

\section{References}

Berlinck, M. T. (1998). Editorial. Revista Latinoamericana de Psicopatologia Fundamental, 1(1), 7-8. Recuperado de: <https://doi.org/10.1590/141547141998001001>.

Gutman, G. (2008). Um companheiro de leituras. Revista Latinoamericana de Psicopatologia Fundamental, 11(3), 514-516. Recuperado de: <https://doi. org/10.1590/S1415-47142008000300017>.

Citação/Citation: D'Agord, M. R. de L. (2020, mar.). Editorial. Cultivating our readers' experience: critical reviews. Revista Latinoamericana de Psicopatologia Fundamental, 23(1), 13-16. http://dx.doi.org/10.1590/1415-4714.2020v23n1p13.2

Editoras/Editors: Profa. Dra. Ana Maria Galdini R. Oda e Profa. Dra. Sonia Leite

Recebido/Received: 10.01.2020 / 01.10.2020 Aceito/Accepted: 10.01.2020 / 01.10.2020

Copyright: (C) 2009 Associação Universitária de Pesquisa em Psicopatologia Fundamental/ University Association for Research in Fundamental Psychopathology. Este é um artigo de livre acesso, que permite uso irrestrito, distribuição e reprodução em qualquer meio, 
desde que o autor e a fonte sejam citados / This is an open-access article, which permits unrestricted use, distribution, and reproduction in any medium, provided the original authors and sources are credited.

\section{Marta Regina de Leão D'Agord}

Psicóloga; Mestre em Filosofia; Doutora em Psicologia; Professora do Departamento de Psicanálise e Psicopatologia e Programa de Pós-Graduação em Psicanálise: Clínica e Cultura do Instituto de Psicologia da Universidade Federal do Rio Grande do Sul UFRGS (Porto Alegre, RS, Br). Pesquisadora Produtividade CNPq (Brasília, DF, Br). Editora Associada da Seção Resenhas Bibliográficas desde 2018.

Rua Riveira 600

90670-160 Porto Alegre, RS, Br

marta.dagord@ufrgs.br

16 https://orcid.org/0000-0003-0379-5323

This is an open-access article, which permits unrestricted use, distribution, BY-NC and reproduction in any medium for non-commercial purposes provided the original authors and sources are credited. 